\title{
STRUCTURAL, THERMAL AND MAGNETIC PROPERTIES OF Fe-Co-Ni-B-Si-Nb BULK AMORPHOUS ALLOY
}

\author{
STRUKTURNE, TERMIČNE IN MAGNETNE LASTNOSTI \\ MASIVNE AMORFNE ZLITINE Fe-Co-Ni-B-Si-Nb
}

\author{
Sabina Lesz ${ }^{1}$, Marcin Nabiałek ${ }^{2}$, Ryszard Nowosielski ${ }^{1}$ \\ ${ }^{1}$ Silesian University of Technology, Institute of Engineering Materials and Biomaterials, Konarskiego Street 18a, 44-100 Gliwice, Poland \\ 2Institute of Physics, Czestochowa University of Technology, Av. Armii Krajowej 19, 42-200 Czestochowa, Poland \\ sabina.lesz@polsl.pl \\ Prejem rokopisa - received: 2014-07-15; sprejem za objavo - accepted for publication: 2014-09-05
}

doi:10.17222/mit.2014.108

\begin{abstract}
In the present paper the structure, thermal stability and magnetic properties of the $\mathrm{Fe}_{43} \mathrm{Co}_{22} \mathrm{Ni}_{7} \mathrm{~B}_{19} \mathrm{Si}_{5} \mathrm{Nb}_{4}$ bulk amorphous alloy were investigated. The investigated alloy was cast as rods with three different diameters. The thermal stability associated with the glass transition temperature $\left(T_{\mathrm{g}}\right)$, crystallization temperature $\left(T_{\mathrm{x}}\right)$ and supercooled-liquid region $\left(\Delta T_{\mathrm{x}}=T_{\mathrm{x}}-T_{\mathrm{g}}\right)$ was examined with differential scanning calorimetry (DSC). The Curie temperature of the investigated glassy rods was determined from the results obtained with the DSC method. The magnetic properties and microstructure of the rods were examined with the vibrating-sample magnetometer (VSM) and X-ray diffraction (XRD) methods, respectively. The crystallization temperature $\left(T_{\mathrm{x}}\right)$ and the glass transition temperature $\left(T_{\mathrm{g}}\right)$ as well as the parameter of $\Delta T_{\mathrm{x}}=T_{\mathrm{x}}-T_{\mathrm{g}}$ as the criterion of the glass-forming ability (GFA) of the investigated alloy were determined. The investigated alloys have good soft-magnetic properties.

Keywords: bulk amorphous alloy, structure, thermal and magnetic properties
\end{abstract}

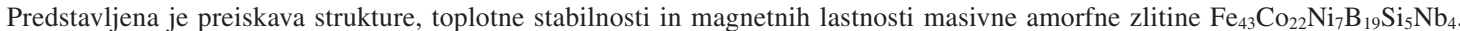
Preiskovana zlitina je bila ulita kot palice s tremi različnimi premeri. Toplotna stabilnost, povezana s prehodom v steklasto stanje $\left(T_{\mathrm{g}}\right)$, temperaturo kristalizacije $\left(T_{\mathrm{x}}\right)$ in s podhlajenim področjem taline $\left(\Delta T_{\mathrm{x}}=T_{\mathrm{x}}-T_{\mathrm{g}}\right)$, je bila preiskovana $\mathrm{z}$ diferenčno vrstično kalorimetrijo (DSC). Curiejeva temperatura preiskovanih steklastih palic je bila določena iz rezultatov, dobljenih pri DSC-metodi. Magnetne lastnosti in mikrostruktura palic so bile preiskane z magnetometrom z vibrirajočimi vzorci (VSM) in z metodo rentgenske difrakcije (XRD). Določeni so bili temperatura kristalizacije $\left(T_{\mathrm{x}}\right)$ in temperatura prehoda v steklasto stanje $\left(T_{\mathrm{g}}\right)$ ter tudi parameter $\Delta T_{\mathrm{x}}=T_{\mathrm{x}}-T_{\mathrm{g}}$ kot merilo sposobnosti tvorbe steklastega stanja (GFA) preiskovanih zlitin. Preiskovane zlitine imajo dobre mehkomagnetne lastnosti.

Ključne besede: masivna amorfna zlitina, struktura, termične in magnetne lastnosti

\section{INTRODUCTION}

A large number of studies on the development of soft-magnetic metallic glasses have been carried out over the last 20 years. It is well recognized that the low glass-forming ability (GFA) of Fe-based alloys has limited the potential of using them as engineering materials. For this reason extensive efforts have been carried out to improve the GFA of metallic materials and the understanding of the mechanism of the effects of various factors on the formation, crystallization, thermal stability and property of bulk metallic glass (BMG). Bulk metallic glasses (BMGs) represent a new class of amorphous metallic alloys. BMGs are valuable materials for environmental applications (e.g., solar cells, hydrogen production, the systems for retention and purification of dangerous pollutants, the nuclear industry, etc.) and for industrial applications in different areas (e.g., aerospace, automotive, electronics, computer, telecommunication areas, etc.). ${ }^{1-12}$

These multi-component metallic alloys can be obtained at low cooling rates of $1 \mathrm{~K} / \mathrm{s}$ to $100 \mathrm{~K} / \mathrm{s}$, which allow an increase in the time (from milliseconds to minutes) before the crystallization, enabling a greater critical casting thickness $(>1 \mathrm{~cm})$ by conventional moulding. ${ }^{1,2,4-7}$

Among BMGs, the Fe-based BMGs are more attractive for application since they do not exhibit only good properties, such as excellent soft-magnetic properties, a high strength and a good corrosion resistance, but are also cheaper in comparison to the other BMGs. ${ }^{1-10}$

For the preparation of a Fe-based $\mathrm{BMG}, \mathrm{Fe}_{80} \mathrm{~B}_{20}$ is often used as the starting alloy. Later the $\mathrm{Nb}$ metal with a high melting temperature is added. The additions of small amounts of $\mathrm{Nb}$ to $(\mathrm{Fe}, \mathrm{Co}, \mathrm{Ni})-(\mathrm{B}, \mathrm{Si})$ alloys are effective for the increase in the GFA through the increase in the stability of the supercooled liquid against crystallization. ${ }^{3}$ A temperature interval of the supercooled-liquid region $\Delta T_{\mathrm{x}}$ has been suggested to evaluate the glass-forming ability (GFA) of bulk amorphous alloys. An addition of amount fraction of $\mathrm{Nb} 4 \%$ was found to be very effective in improving the GFA of Fe- and Co-based glassy alloys. ${ }^{7}$

As BMGs can be produced by adding four and five elements to the basic ternary alloys, small amounts of the elements such $\mathrm{Ni}, \mathrm{Co}$ and $\mathrm{Si}$ were added. A partial substitution of $\mathrm{Fe}$ with the other magnetic elements, Ni or 
Co, may significantly enhance the GFA and soft-magnetic properties of the Fe-based glass-forming alloys. The metalloid elements of $\mathrm{Si}$ and B play a crucial role in the formation of BMGs. They also affect the GFA, the thermal stability, the crystallization and the properties of BMGs. These materials have a strong affinity with the conventional BMG base elements such Fe and rare-earth elements, i.e., they have a large, negative heat of mixing with these base elements. The metalloid elements result in crystallization, degrading the GFA of the BMGs, but, on the other hand, due to a small atomic size of the $\mathrm{Si}$ and $\mathrm{B}$ atoms, a proper addition can tighten the alloy structure, stabilizing the alloy against crystallization. ${ }^{3}$

The Fe-Co based glassy alloys exhibit good softmagnetic properties, i.e., a high saturation magnetization $(0.8-1.3 \mathrm{~T})$ and a low coercivity $(1-2.5 \mathrm{~A} / \mathrm{m}) .{ }^{3}$ Magnetic properties of these alloys are dependent on the $\mathrm{Ni}$ and $\mathrm{Fe}$ contents. A decrease in the coercivity $\left(H_{\mathrm{c}}\right)$ with the increasing Co content was found to originate in the reduction of saturation magnetostriction. ${ }^{3}$ Coercivity $H_{\mathrm{c}}$ is proportional to the ratio of saturation magnetostriction $\left(\lambda_{\mathrm{s}}\right)$ to saturation magnetization $\left(J_{\mathrm{s}}\right)$, i.e..$^{8}$

$$
H_{\mathrm{c}} \approx \Delta V \cdot \sqrt{\rho d \frac{\lambda_{\mathrm{s}}}{J_{\mathrm{s}}}}
$$

and the slope is related to the volume $(\Delta V)$ and density $(\rho d)$ of internal defects in the glassy structure. ${ }^{8}$

Due to their unique properties, the Fe-Co based glassy alloys have been commercialized in the following application fields: precision-mould material, precisionimprint material, precision-sensor material, precisionmachinery material, surface-coating material, cuttingtool material, shot penning material, fuel-cell separator material and so forth. ${ }^{1,2,9,10}$

In the present paper the structural, thermal and magnetic properties of a $\mathrm{Fe}-\mathrm{Co}-\mathrm{Ni}-\mathrm{B}-\mathrm{Si}-\mathrm{Nb}$ bulk amorphous alloy with a selected chemical composition was investigated.

\section{EXPERIMENTAL PROCEDURE}

Investigations were carried out on amorphous rods with a composition of $\left[\left(\mathrm{Fe}_{0.6} \mathrm{Co}_{0.3} \mathrm{Ni}_{0.1}\right)_{0.75} \mathrm{~B}_{0.2} \mathrm{Si}_{0.05}\right]_{96} \mathrm{Nb}_{4}$. Fe-based master-alloy ingots with a composition of $\left[\left(\mathrm{Fe}_{0.6} \mathrm{Co}_{0.3} \mathrm{Ni}_{0.1}\right)_{0.75} \mathrm{~B}_{0.2} \mathrm{Si}_{0.05}\right]_{96} \mathrm{Nb}_{4}$ were prepared by induction melting of pure $\mathrm{Fe}, \mathrm{Co}, \mathrm{Ni}, \mathrm{Nb}$ and pure $\mathrm{B}$ and $\mathrm{Si}$ crystals in an argon atmosphere. The $\mathrm{Fe}_{43} \mathrm{Co}_{22} \mathrm{Ni}_{7} \mathrm{~B}_{19} \mathrm{Si}_{5} \mathrm{Nb}_{4}$ alloy composition represents the nominal atomic percentages. The master alloy was melted in a quartz crucible using an induction coil. Rods with $(1.5,2.5$ and 3$) \mathrm{mm}$ diameters were prepared with the pressure copper-mould casting method. ${ }^{11}$

The microstructure of the rods was examined with the X-ray diffraction (XRD) method. The X-ray method was performed using a Seifert-FPM XRD 7 diffractometer with filtered Co-K $\alpha$ radiation.
The thermal stability associated with the glass transition temperature $\left(T_{g}\right)$, crystallization temperature $\left(T_{\mathrm{x}}\right)$ and supercooled-liquid region $\left(\Delta T_{\mathrm{x}}=T_{\mathrm{x}}-T_{\mathrm{g}}\right)$ was examined with differential scanning calorimetry (DSC) at a heating rate of $0.1 \mathrm{~K} / \mathrm{s}$. The Curie temperature of the investigated glassy rods was determined from the results obtained with the DSC method.

High-field magnetization curves were measured with a vibrating-sample magnetometer (VSM) in a magnetic field up to $2 \mathrm{~T}$. The magnetizing field was parallel to the sample length to minimize the demagnetization effect. The magnetization curves were analyzed using the leastsquares method.

\section{RESULTS AND DISCUSSION}

It was found from the obtained results of the structural studies performed with X-ray diffraction that the diffraction patterns of the surface rods with $(1.5,2.5$ and 3.0) $\mathrm{mm}$ diameters of the $\mathrm{Fe}_{43} \mathrm{Co}_{22} \mathrm{Ni}_{7} \mathrm{~B}_{19} \mathrm{Si}_{5} \mathrm{Nb}_{4}$ alloy consist of a broad-angle peak, indicating the existence of an amorphous phase (Figure 1).

The DSC curves determined on the $\mathrm{Fe}_{43} \mathrm{Co}_{22} \mathrm{Ni}_{7} \mathrm{~B}_{19} \mathrm{Si}_{5} \mathrm{Nb}_{4}$ rods with the diameters of $(1.5,2.5$ and 3$) \mathrm{mm}$ in the as-cast state for the studied alloy are shown in Figures 2 to $\mathbf{4}$, and summarized in Table $\mathbf{1 .}$ Table 1 also gives information about the thermal properties of the studied amorphous-alloy rods. The onset crystallization temperatures $T_{x}$ for the glassy rod samples with the diameters of $(1.5,2.5$ and 3$) \mathrm{mm}$ are slightly different and equal to $(828,827$ and 826) K (Figures 2 to 4), respectively. It is seen that $T_{\mathrm{x}}$ decreases from $828 \mathrm{~K}$ to $826 \mathrm{~K}$ with an increase in the diameter of the rods. On the basis of an analysis of DSC curves the glass transition temperature $T_{\mathrm{g}}$ and supercooled-liquid region

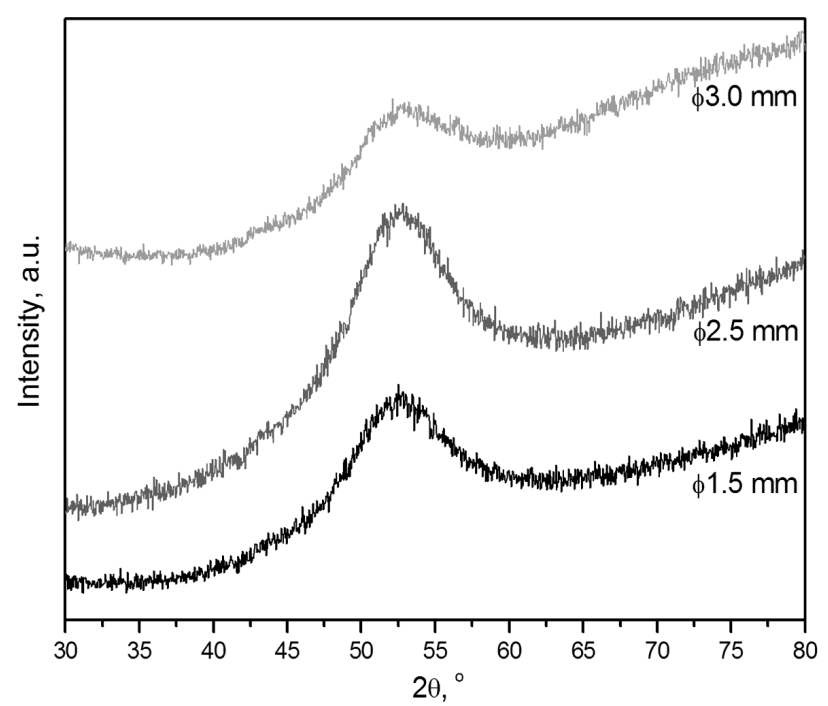

Figure 1: X-ray diffraction patterns of the bulk amorphous $\mathrm{Fe}_{43} \mathrm{Co}_{22} \mathrm{Ni}_{7} \mathrm{~B}_{19} \mathrm{Si}_{5} \mathrm{Nb}_{4}$ rods

Slika 1: Rentgenogrami masivnih amorfnih palic $\mathrm{Fe}_{43} \mathrm{Co}_{22} \mathrm{Ni}_{7} \mathrm{~B}_{19} \mathrm{Si}_{5} \mathrm{Nb}_{4}$ 


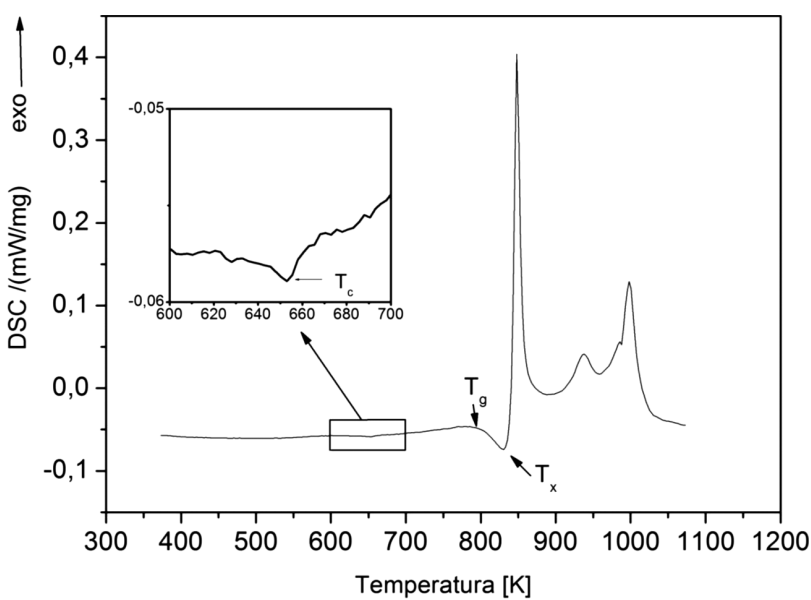

Figure 2: DSC curve of the $\mathrm{Fe}_{43} \mathrm{Co}_{22} \mathrm{Ni}_{7} \mathrm{~B}_{19} \mathrm{Si}_{5} \mathrm{Nb}_{4}$ glassy-alloy rod with a diameter of $1.5 \mathrm{~mm}$

Slika 2: DSC-krivulja palice premera $1,5 \mathrm{~mm}$ iz steklaste zlitine $\mathrm{Fe}_{43} \mathrm{Co}_{22} \mathrm{Ni}_{7} \mathrm{~B}_{19} \mathrm{Si}_{5} \mathrm{Nb}_{4}$

$\Delta T_{\mathrm{x}}=T_{\mathrm{x}}-T_{\mathrm{g}}$ for the glassy rod samples with the diameters of $1.5 \mathrm{~mm}$ to $3 \mathrm{~mm}$ are determined, too. The value of the supercooled-liquid region is an experimental parameter that determines the glass-forming ability of the tested alloy. The glass transition temperature $T_{\mathrm{g}}$ and supercooled-liquid region $\Delta T_{\mathrm{x}}$ for the glassy rod samples with the diameters of $(1.5,2.5$ and 3$) \mathrm{mm}$ are: $T_{\mathrm{g}}=794 \mathrm{~K}, \Delta T_{\mathrm{x}}=34 \mathrm{~K}($ Figure 2$), T_{\mathrm{g}}=790 \mathrm{~K}, \Delta T_{\mathrm{x}}$ $=37 \mathrm{~K}\left(\right.$ Figure 3), $T_{\mathrm{g}}=797 \mathrm{~K}, \Delta T_{\mathrm{x}}=29 \mathrm{~K}($ Figure 4), respectively. The value of the Curie temperature $T_{\mathrm{C}}$ for the $\mathrm{Fe}_{43} \mathrm{Co}_{22} \mathrm{Ni}_{7} \mathrm{~B}_{19} \mathrm{Si}_{5} \mathrm{Nb}_{4}$ rods with the diameters of (1.5, 2.5 and 3.0) $\mathrm{mm}$ is $(652,650$ and 655$) \mathrm{K}$, respectively. Similar values of $T_{\mathrm{g}}$ and $T_{\mathrm{C}}$ were obtained in ${ }^{1,9}$, where the results are $T_{\mathrm{g}}=813 \mathrm{~K}$ and $T_{\mathrm{C}}=643 \mathrm{~K}$ for the $\left[\left(\mathrm{Fe}_{0.6} \mathrm{Co}_{0.3} \mathrm{Ni}_{0.1}\right)_{0.75} \mathrm{~B}_{0.2} \mathrm{Si}_{0.05}\right]_{96} \mathrm{Nb}_{4}$ alloy in the form of a rod with a diameter of $4 \mathrm{~mm}$.

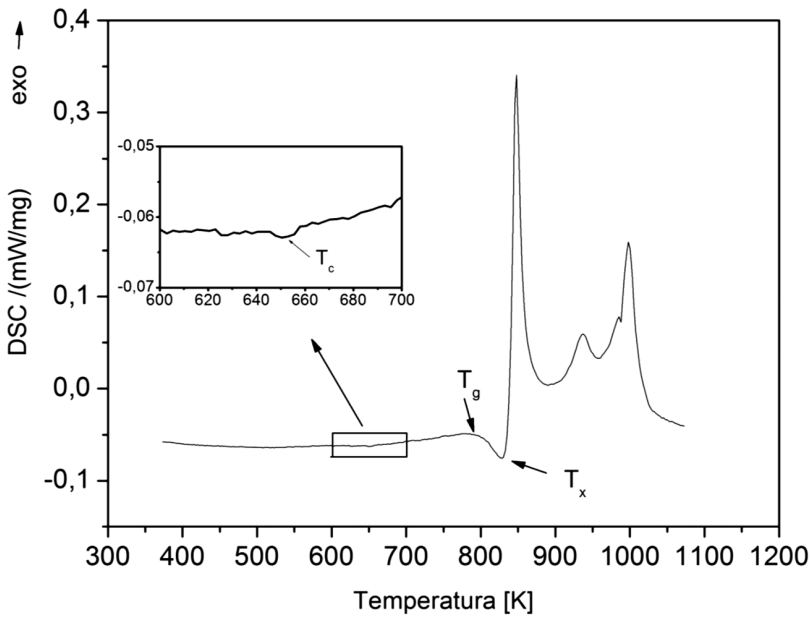

Figure 3: DSC curve of the $\mathrm{Fe}_{43} \mathrm{Co}_{22} \mathrm{Ni}_{7} \mathrm{~B}_{19} \mathrm{Si}_{5} \mathrm{Nb}_{4}$ glassy-alloy rod with a diameter of $2.5 \mathrm{~mm}$

Slika 3: DSC-krivulja palice premera $2,5 \mathrm{~mm}$ iz steklaste zlitine $\mathrm{Fe}_{43} \mathrm{Co}_{22} \mathrm{Ni}_{7} \mathrm{~B}_{19} \mathrm{Si}_{5} \mathrm{Nb}_{4}$

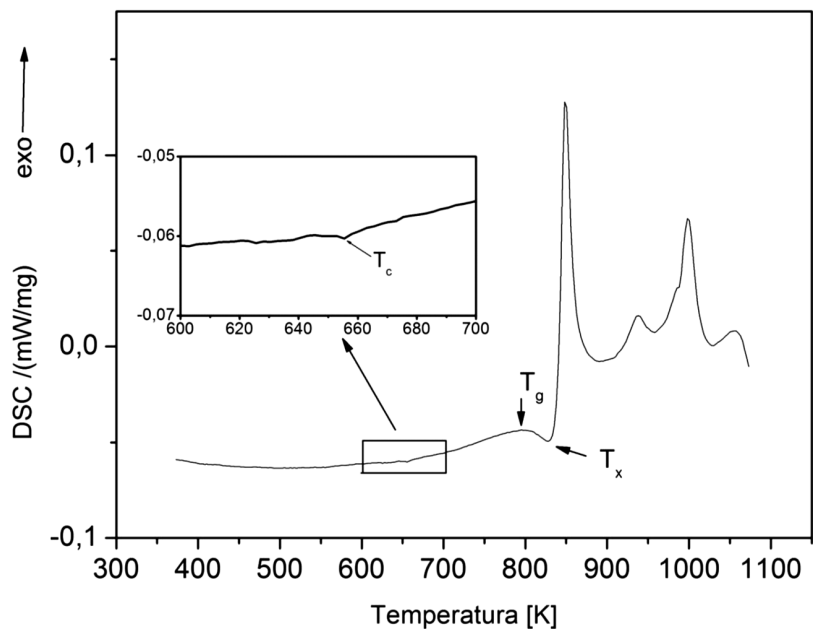

Figure 4: DSC curve of the $\mathrm{Fe}_{43} \mathrm{Co}_{22} \mathrm{Ni}_{7} \mathrm{~B}_{19} \mathrm{Si}_{5} \mathrm{Nb}_{4}$ glassy-alloy rod with a diameter of $3.0 \mathrm{~mm}$

Slika 4: DSC-krivulja palice premera 3,0 $\mathrm{mm}$ iz steklaste zlitine $\mathrm{Fe}_{43} \mathrm{Co}_{22} \mathrm{Ni}_{7} \mathrm{~B}_{19} \mathrm{Si}_{5} \mathrm{Nb}_{4}$

Table 1: Thermal $\left(T_{\mathrm{g}}-\right.$ the glass transition temperature, $T_{\mathrm{x}}-$ the crystallization temperature, $\Delta T_{\mathrm{x}}-$ the temperature interval of the supercooled-liquid region) and magnetic $\left(T_{\mathrm{C}}-\right.$ the Curie temperature, $M_{\mathrm{S}}$ - the saturation induction) properties of the bulk glassy $\mathrm{Fe}_{43} \mathrm{Co}_{22} \mathrm{Ni}_{7} \mathrm{~B}_{19} \mathrm{Si}_{5} \mathrm{Nb}_{4}$ rods with the diameters of $(1.5,2.5$ and 3.0$)$ $\mathrm{mm}$

Tabela 1: Termične $\left(T_{\mathrm{g}}\right.$ - temperatura prehoda v steklasto stanje, $T_{\mathrm{x}}-$ temperatura kristalizacije, $\Delta T_{\mathrm{X}}$ - temperaturni interval področja superpodhlajene taline) in magnetne $\left(T_{\mathrm{C}}-\right.$ Curiejeva temperatura, $M_{\mathrm{S}}$ - nasičenje indukcije) lastnosti masivnih steklastih palic $\mathrm{Fe}_{43} \mathrm{Co}_{22} \mathrm{Ni}_{7} \mathrm{~B}_{19} \mathrm{Si}_{5} \mathrm{Nb}_{4}$ s premeri $(1,5,2,5$ in 3,0$) \mathrm{mm}$

\begin{tabular}{|c|c|c|c|c|c|}
\hline Diameter & \multicolumn{3}{|c|}{ Thermal properties } & \multicolumn{2}{c|}{ Magnetic properties } \\
\hline$\Phi / \mathrm{mm}$ & $T_{\mathrm{g}} / \mathrm{K}$ & $T_{\mathrm{x}} / \mathrm{K}$ & $\begin{array}{c}\Delta T_{\mathrm{X}} / \mathrm{K}= \\
T_{\mathrm{x}}-T_{\mathrm{g}}\end{array}$ & $T_{\mathrm{C}} / \mathrm{K}$ & $M_{\mathrm{S}} / \mathrm{T}$ \\
\hline 1.5 & 794 & 828 & 34 & 652 & 1.07 \\
\hline 2.5 & 790 & 827 & 37 & 650 & 1.22 \\
\hline 3.0 & 797 & 826 & 29 & 655 & 1.18 \\
\hline
\end{tabular}

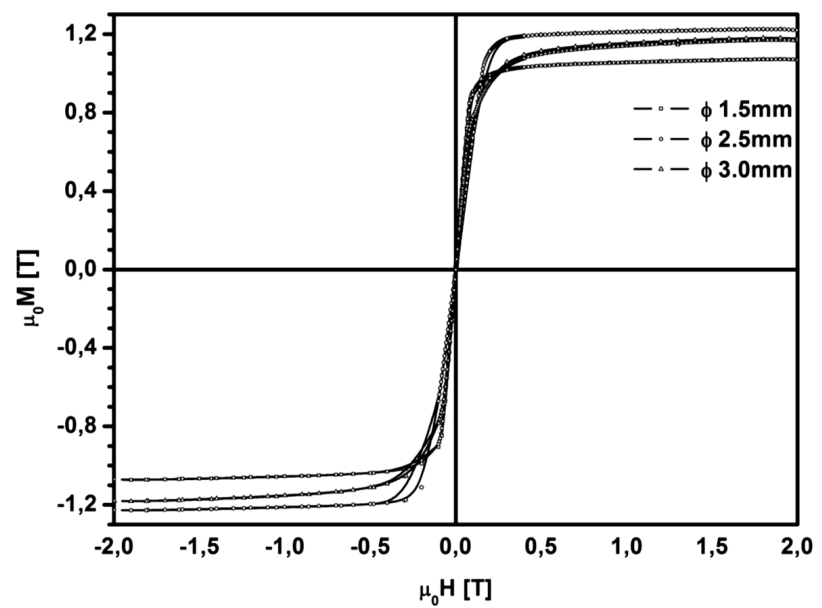

Figure 5: Magnetic hysteresis loops of the bulk amorphous $\mathrm{Fe}_{43} \mathrm{Co}_{22} \mathrm{Ni}_{7} \mathrm{~B}_{19} \mathrm{Si}_{5} \mathrm{Nb}_{4}$ rods

Slika 5: Magnetne histerezne zanke masivnih steklastih palic $\mathrm{Fe}_{43} \mathrm{Co}_{22} \mathrm{Ni}_{7} \mathrm{~B}_{19} \mathrm{Si}_{5} \mathrm{Nb}_{4}$ 
The saturation induction $\left(M_{\mathrm{s}}\right)$ of the studied glassy rods is $(1.07,1.22$ and 1.18$) \mathrm{T}$ for the samples with the diameters of $(1.5,2.5$ and 3$) \mathrm{mm}$, respectively (Figure 5).

The obtained magnetic properties allow us to classify the studied bulk amorphous alloy in the as-cast state as a soft-magnetic material. These excellent magnetic properties lead us to believe that the Fe-based amorphous alloy could be used as a new engineering and functional material intended for the parts of inductive components.

\section{CONCLUSIONS}

Bulk metallic glass rods with the diameters of (1.5, 2.5 and 3) $\mathrm{mm}$ and a composition of $\mathrm{Fe}_{43} \mathrm{Co}_{22} \mathrm{Ni}_{7} \mathrm{~B}_{19} \mathrm{Si}_{5} \mathrm{Nb}_{4}$ were made by pressure copper-mould casting. The glassy rods show good softmagnetic properties and thermal stability.

A high magnetization of $1.07 \mathrm{~T}$ to $1.22 \mathrm{~T}$ of the $\mathrm{Fe}_{43} \mathrm{Co}_{22} \mathrm{Ni}_{7} \mathrm{~B}_{19} \mathrm{Si}_{5} \mathrm{Nb}_{4}$ rods leads us to believe that the Fe-based bulk glassy alloy with a $\mathrm{Ni}$ addition will be used as a new engineering material for the parts of micro-motors, force sensors and other applications. Moreover, force sensors based on the newly developed amorphous alloys may operate in a high-temperature range. The temperature of the operation of such a sensor is limited mainly by the Curie temperature and the value of $T_{\mathrm{C}}$ for the $\mathrm{Fe}_{43} \mathrm{Co}_{22} \mathrm{Ni}_{7} \mathrm{~B}_{19} \mathrm{Si}_{5} \mathrm{Nb}_{4}$ alloy is in the range from $650 \mathrm{~K}$ to $655 \mathrm{~K}$.

\section{REFERENCES}

${ }^{1}$ A. Inoue, B. L. Shen, C. T. Chan, Fe- and Co-based bulk glassy alloys with ultrahigh strength of over $4000 \mathrm{MPa}$, Intermetallics, 14 (2006), 936-944, doi:10.1016/j.intermet.2006.01.038
${ }^{2}$ A. Inoue, B. Shen, A. Takeuchi, Properties and applications of bulk glassy alloys in late transition metal-based systems, Materials Science and Engineering, A 441 (2006), 18-25, doi:10.1016/j.msea. 2006.02.416

${ }^{3}$ W. H. Wang, Roles of minor additions in formation and properties of bulk metallic glasses, Progress in Materials Science, 52 (2007), 540-596, doi:10.1016/j.pmatsci.2006.07.003

${ }^{4}$ A. Inoue, Stabilization of metallic supercooled liquid and bulk amorphous alloys, Acta Materialia, 48 (2000), 279-306, doi:10.1016/ s1359-6454(99)00300-6

${ }^{5}$ B. Shen, A. Inoue, C. Chang, Superhigh strength and good soft-magnetic properties of $(\mathrm{Fe}, \mathrm{Co})-\mathrm{B}-\mathrm{Si}-\mathrm{Nb}$ bulk glassy alloys with high glass-forming ability, Applied Physics Letters, 85 (2004) 21, 4911-4913, doi:10.1063/1.1827349

${ }^{6}$ K. F. Yao, C. Q. Zhang, Fe-based bulk metallic glass with high plasticity, Applied Physics Letters, 90 (2007), 061901, doi:10.1063/ 1.2437722

${ }^{7}$ C. Chang, B. Shen, A. Inoue, FeNi-based bulk glassy alloys with superhigh mechanical strength and excellent soft magnetic properties, Applied Physics Letters, 89 (2006) 5, 051912, doi:10.1063/ 1.2266702

${ }^{8}$ T. Bitoh, A. Makino, A. Inoue, Origin of Low Coercivity of Fe-(Al, Ga)-(P, C, B, Si, Ge) Bulk Glassy Alloys, Materials Transactions, 44 (2003) 10, 2020-2024

${ }^{9}$ B. Shen, C. Chang, A. Inoue, Formation, ductile deformation behavior and soft-magnetic properties of $(\mathrm{Fe}, \mathrm{Co}, \mathrm{Ni})-\mathrm{B}-\mathrm{Si}-\mathrm{Nb}$ bulk glassy alloys, Intermetallics, 15 (2007), 9-16, doi:10.1016/j.intermet. 2005.11.037

${ }^{10}$ S. Lesz, R. Babilas, M. Nabialek, M. Szota, M. Dospial, R. Nowosielski, The characterization of structure, thermal stability and magnetic properties of $\mathrm{Fe}-\mathrm{Co}-\mathrm{B}-\mathrm{Si}-\mathrm{Nb}$ bulk amorphous and nanocrystalline alloys, Journal of Alloys and Compounds, 509 (2011), 197-201, doi:10.1016/j.jallcom.2010.12.146

${ }^{11}$ R. Nowosielski, R. Babilas, G. Dercz, L. Pajak, Structure of Febased metallic glass after crystallization process, Solid State Phenomena, 163 (2010), 165-168, doi:10.4028/www.scientific.net/SSP. 163.165

${ }^{12}$ L. A. Dobrzański, A. Drygala, Influence of Laser Processing on Polycrystalline Silicon Surface, Materials Science Forum, 706-709 (2012), 829-834, doi:10.4028/www.scientific.net/MSF.706-709.829 